\title{
A Research on Pre-Monsoon and Post- Monsoon Physico-Chemical Parameters of Groundwater of Velliangadu Village, Coimbatore, Tamilnadu, India
}

\author{
K. Karthik, R.Mayildurai, S. Karthikeyan
}

\begin{abstract}
Groundwater quality plays an important role in conservation of water resources not only for the present generation but also for the future generation. Each and every harvest season witness excessive use of pesticides and fertilizers in the agricultural fields. During a monsoon season these potential hazards leaches into the soil and mixes with the groundwater. This paper aimed at studying the Physico chemical parameters of pre- and post-monsoon groundwater quality of Velliangadu Village of Coimbatore district in the state of Tamil Nadu to reveal the water quality parameters before and after a monsoon season. The Physico-chemical parameters considered for drinking water like $\mathrm{pH}$, electrical conductivity, total dissolved solids, total alkalinity, total hardness, dissolved oxygen, chlorides etc. were analysed for pre-monsoon and postmonsoon groundwater samples collected from different areas and compared.
\end{abstract}

Keywords: Post monsoon, pre monsoon, Velliangadu, Water quality

\section{INTRODUCTION}

Although the amount of water on the earth surface is plenty, the available fresh quality water is thinning because of the over exploitation of water resources. Excessive use of fertilizers $^{1}$, discharge of sewage effluents in the water bodies $^{2}$, the interaction of rock and water in a region ${ }^{3}$, dumping of wastes nearby the water bodies ${ }^{4}$ are some of the causes for the contamination of water. The use of water for drinking and irrigation purpose depends on its quality. The global climatic changes and use of excessive fertilizers and pesticides threatens the availability of fresh water for drinking and agricultural purposes. Velliangadu is one of the villages in Coimbatore where inorganic fertilizers are commonly applied by the farmers to overcome nutrient deficiency in permanent agricultural lands. However, use of excessive fertilizer and pesticides can cause severe environmental and health problems. During a rainfall season the fertilizers used in the agricultural field leaches in to the ground and mixes with the water. Eutrophication and nitrate pollution are among the major problems of these fertilizers. Since groundwater is the major source for agriculture in this area, this study attempted to assess the seasonal variation of physico-chemical properties of groundwater. The amount of

Revised Manuscript Received on July 18, 2019.

K. Karthik, Department of Chemistry, Kumaraguru College of Technology,Coimbatore-641049,TN,India.(E-mail:

karthikchemics84@gmail.com)

R.Mayildurai, Department of Chemistry, Kumaraguru College of Technology, Coimbatore- 641049, TN, India.

S. Karthikeyan, Department of Civil Engineering, Kumaraguru College of Technology, Coimbatore- 641049, TN, India. nutrients mixes with the water defines the quality. The nature of soil and rock in an area has an impact on its groundwater quality. This paper compares the quality of groundwater before and after the monsoon rainfall in Velliangadu village of Coimbatore, Tamilnadu, India.

\section{EXPERIMENTAL \& RESULTS}

\section{Area of Study}

To assess the seasonal variations in the physicochemical properties of ground water of Velliangadu village, Coimbatore, Tamilnadu, India, water samples have been collected from seven different places. Water samples have been collected from both pre monsoon and post monsoon seasons from the bore-wells. The depth of the bore wells are ranged from 250 - 500 feet. During the pre-monsoon period seven water samples have collected and analysed for physicochemical parameters. After monsoon period seven water samples from the same places have been collected, analysed for physicochemical parameters and compared with the pre monsoon parameters. The places ${ }^{5}$ from which the water samples have been collected is given in Table 1. The Latitude (N) and Longitude (E) of the places were identified using the google maps.

Table. 1: Location details of places

\begin{tabular}{|c|c|c|c|}
\hline S.No. & Sample Code & Latitude (N) & Longitude (E) \\
\hline 1 & S1 & $11^{\circ} 12^{\prime} 05^{\prime \prime}$ & $76^{\circ} 49^{\prime} 49^{\prime \prime}$ \\
\hline 2 & S2 & $1^{\circ} 11^{\prime} 56^{\prime \prime}$ & $76^{\circ} 50^{\prime} 27^{\prime \prime}$ \\
\hline 3 & S3 & $1^{\circ} 12^{\prime} 20^{\prime \prime}$ & $76^{\circ} 50^{\prime} 16^{\prime \prime}$ \\
\hline 4 & S4 & $1^{\circ} 12^{\prime} 20^{\prime \prime}$ & $76^{\circ} 49^{\prime} 43^{\prime \prime}$ \\
\hline 5 & S5 & $1^{\circ} 12^{\prime} 24^{\prime \prime}$ & $76^{\circ} 49^{\prime} 35^{\prime \prime}$ \\
\hline 6 & S6 & $11^{\circ} 12^{\prime} 17^{\prime \prime}$ & $76^{\circ} 49^{\prime} 35^{\prime \prime}$ \\
\hline 7 & S7 & $11^{\circ} 12^{\prime} 10^{\prime \prime}$ & $76^{\circ} 49^{\prime} 20^{\prime \prime}$ \\
\hline
\end{tabular}

Sample Collection

All the fourteen water samples have been collected in clean water containers. The containers were cleanly rinsed before collecting the water samples, tightly closed and labelled as S1, S2, S3, S4, S5, S6 and S7. All the water samples have been analysed for physicochemical parameters in the laboratory. 


\section{A RESEARCH ON PRE-MONSOON AND POST-MONSOON PHYSICO-CHEMICAL PARAMETERS OF GROUNDWATER OF VELLIANGADU VILLAGE, COIMBATORE, TAMILNADU, INDIA}

\section{Physicochemical analysis of water samples}

All the fourteen water samples both from pre monsoon and post monsoon have been analyzed for various water quality parameters such as $\mathrm{pH}$, Total Dissolved Solids (TDS), Total Hardness, Total Alkalinity, Chloride and Electrical Conductivity. The $\mathrm{pH}$ of the water samples have been determined by using standard $\mathrm{pH}$ meter. The total dissolved solids of the water samples determined using the standard methods given by APHA $^{6}$. EDTA titrimetric method was employed for the total hardness determination. Argentometric Titration method was followed to determine the chloride content of the water samples. The electrical conductivity of the water samples have been measured using standard conductivity meter.

\section{Results and Discussion}

The analytical data on physicochemical properties of all the water samples is reproduced in Table 2

Table. 2: Physicochemical parameters of pre monsoon and post monsoon water samples

\begin{tabular}{|c|c|c|c|c|c|c|c|c|c|c|c|c|c|c|}
\hline \multirow{2}{*}{$\begin{array}{c}\text { Parameter } \\
\text { s }\end{array}$} & \multicolumn{2}{|c|}{ S1 } & \multicolumn{2}{|c|}{ S2 } & \multicolumn{2}{|c|}{ S3 } & \multicolumn{2}{|c|}{ S4 } & \multicolumn{2}{|c|}{ S5 } & \multicolumn{2}{|c|}{ S6 } & \multicolumn{2}{|c|}{ S7 } \\
\hline & $\operatorname{Pr}$ & Po & $\operatorname{Pr}$ & Po & $\operatorname{Pr}$ & Po & $\operatorname{Pr}$ & Po & $\operatorname{Pr}$ & Po & $\operatorname{Pr}$ & Po & $\operatorname{Pr}$ & Po \\
\hline $\mathrm{pH}$ & 7.4 & 7.5 & 7.6 & 7.7 & 7.4 & 7.5 & 7.6 & 7.6 & 7.5 & 7.7 & 7.7 & 7.7 & 7.3 & 7.4 \\
\hline TH & 465 & 519 & 511 & 578 & $\begin{array}{c}47 \\
2\end{array}$ & 612 & 271 & 298 & $\begin{array}{c}26 \\
9\end{array}$ & 300 & 389 & 422 & 380 & 400 \\
\hline TDS & 714 & 905 & 678 & 717 & 490 & 669 & 475 & 515 & $\begin{array}{c}60 \\
8\end{array}$ & 673 & 683 & 673 & 926 & 901 \\
\hline Alkalinity & 289 & 456 & 295 & 451 & $\begin{array}{c}22 \\
6\end{array}$ & 348 & 285 & 345 & $\begin{array}{c}33 \\
3\end{array}$ & 556 & 353 & 556 & 444 & 636 \\
\hline $\mathrm{Cl}$ & 118 & 121 & 102 & 115 & 99 & 110 & 51 & 66 & 83 & 108 & 131 & 138 & 195 & 223 \\
\hline EC & 1.49 & 1.85 & 1.37 & 1.47 & 1.04 & 1.35 & 0.99 & 1.11 & 1.21 & 1.36 & 1.37 & 1.36 & 1.90 & 1.83 \\
\hline
\end{tabular}

From Table 2 it is evident that the $\mathrm{pH}$ of the water samples in both pre and post monsoon lies within the range prescribed for drinking and agricultural purpose by various agencies like $\mathrm{WHO}^{7}, \mathrm{BIS}^{8}$ and $\mathrm{ICMR}^{9}$. The Total hardness of the water samples collected during post monsoon has high values than the pre monsoon water samples. The hardness of water samples is mainly because of the presence of calcium and magnesium salts. The major cause of high levels of total hardness in post monsoon water samples can be attributed to the type of soils and rocks present in the region since there are no industries, factories or other polluting sources present. Except the water samples S6 and S7, the total dissolved solids is higher in post monsoon water samples than pre monsoon samples. The total dissolved solids also contributed by the type of soil through which the water leaches in to the ground during rainfalls. The amount of fertilizers applied in the agricultural field could also contribute to the total dissolved solids.

The total alkalinity of the water samples represented in Table 2 reveals that the total alkalinity of post monsoon water samples are higher compared with the pre monsoon water samples. The alkalinity of water samples are mainly due to the presence of hydroxyl, carbonate, phosphate and bicarbonate ions present in a water resource. The amount of fertilizers applied in the agricultural lands may play a role in higher amount of total alkalinity in post monsoon water samples. The soil and rocks present in the region could also play a role in the total alkalinity of the water samples of post monsoon. The chloride content of the post monsoon water samples are higher than that of pre monsoon water samples and the difference is lesser compared with other parameters. The chloride content in water is mainly because of chloride salts which may be from soils and the low levels of chloride content reveals that the area is not get polluted by chloride contamination. The chloride contents of pre and post monsoon water samples are within the range prescribed by the agencies for drinking purpos ${ }^{7,8,9}$ and agricultural use. The low levels of chloride content in all the water samples revels that the underground water in the region is not polluted and can be used for both drinking and agricultural purpose.

The electrical conductivity of the water samples gives an idea on the amount of free ions present in the water samples. Except water samples S6 and S7 the conductivity of post monsoon water samples are higher than the pre monsoon water samples. The amount of salts dissolved in the water is responsible for the conductivity and the rainfall increases the conducting ions present in water samples by dissolving more amount of rocks.

\section{CONCLUSION}

The physicochemical parameters of pre monsoon and post monsoon groundwater samples of Velliangadu area have been analysed. $\mathrm{pH}$ of the water samples is in the ranges prescribed by various agencies and found to be good for drinking as well as agricultural purposes. The total hardness, total dissolved solids, alkalinity and electrical conductivity are higher in post monsoon water samples than the pre monsoon water samples. The presence of soil type in the region, rock present in the area and the high amount of fertilisers applied in the agricultural lands could be the cause of increase in physicochemical parameter values.

\section{REFERENCES}

1. Kondraju, T. T.; Rajan, K. S, ISPRS Ann. Photogramm. Remote Sens. Spatial Inf. Sci., 2019, IV-3/W1, 17-23.

2. Yadav, S.; Rao, S. Environmental Biotechnology For Soil and Wastewater Implications on Ecosystems. Springer, Singapore 2019

3. Rao, K.N.; Latha, P.S., Arab J Geosci 2019, 12, 267. 
4. Sachin, M.; Dhanesh, T.; Anurag, O.; Ashwani Kumar A., Groundwater for Sustainable Development 2019, 100230

5. https://www.google.com/maps

6. APHA, Standard methods for the examination of water and waste water, American Public Health Association, Washington, 1989

7. W.H.O, Guidelines for drinking water quality, Vol.1, Recommendations WHO, Geneva, 1984.

8. IS: 10500 : 2012, Indian standard drinking water specification (Second revision). Bureau of Indian Standards (BIS), New Delhi, India. 2015

9. ICMR. Manual standards of quality of drinking water supplies. 1975. 